\title{
Trends in recovery of Mediterranean soil chemical properties and microbial activities after infrequent and frequent wildfires
}

\author{
René Guénon ${ }^{1}$, Michel Vennetier ${ }^{2+4}$, Nathalie Dupuy ${ }^{3}$, Sevastianos Roussos ${ }^{1}$, Alexia \\ Pailler $^{1}$, Raphaël Gros ${ }^{1+4^{*}}$ \\ ${ }^{1}$ Institut Méditerranéen d'Ecologie et de Paléoécologie, UMR CNRS 6116 IRD 193, Equipe Ecologie \\ Microbienne et Biotechnologie, Service 452, Faculté des Sciences et Techniques de Saint-Jérôme, \\ Université Paul Cézanne Aix-Marseille 3, 13397 Marseille cedex 20, France \\ ${ }^{2}$ Cemagref, 3275 route de Cézanne, CS 40061, 13182 Aix en Provence Cedex 5 France \\ ${ }^{3}$ Institut des Sciences Moléculaires de Marseille, UMR CNRS 6263, équipe $\mathrm{AD}^{2} \mathrm{EM}$, groupe systèmes \\ chimiques complexes, service 451, Université Paul Cézanne Aix-Marseille, Faculté des Sciences et \\ Techniques de Saint-Jérôme 13397 Marseille cedex 20, France \\ ${ }^{4}$ Fédération de Recherche ECCOREV (FR 3098), Europôle Méditerranéen de l'Arbois, Bâtiment du \\ CEREGE BP 80, 13545 Aix en Provence cedex 4 \\ *corresponding author: R. Gros \\ Phone: + 33 (0)491 288768 \\ Fax: +33(0)491288 190 \\ E-mail : raphael.gros@univ-cezanne.fr
}

\begin{abstract}
Since the 1970s, increase in fire frequency has been observed in all European Mediterranean regions. The objectives of this study were 1) to determine the effects of wildfire frequency on the recovery at short and long-term of soil chemical and microbial properties and 2) to identify the mechanisms underlying the recovery of these sites properties. Soils from seventeen plots (Maures mountains range, Var, France) were classified into five wildfire regimes (i.e. not burned since at least 57 years, infrequently and frequently burned both with time since fire for 4 and 17 years). Soil samples from these plots were analysed for their nutrient content, chemical functions of soil organic matter (SOM) using FT-MIR spectroscopy and microbial mineralising activities. Our results showed that the frequent wildfire regime slowed down the recovery at short term of SOM spectroscopic properties and nutrient availability. Both low quantity and low quality (i.e. high percentage of aromatic and phenolic organic forms) of soil organic matter were found related to soil microbial recovery four years after frequent wildfires. The frequent wildfires improved the recovery in net nitrification and nitrate content, leading to an increase in catabolic evenness and a recovery in microbial C-substrate utilisation profiles between 4 and 17 years. However, frequent wildfires slowed down the recovery of hydrolytic enzyme pool (i.e. FDA hydrolases) and phenol oxidase activity, both involved in soil $\mathrm{C}$ cycling. Overall, our observations suggest that 4 fires in 50 years is a threshold beyond which soil quality may be endangered.
\end{abstract}

Keywords: Recurrent wildfires, resilience, enzyme activities, Biolog®, Nmineralisation, FT-MIR spectroscopy.

\section{Introduction}

Wildfire is a historical disturbance which has played a large role in shaping ecology and evolution of Mediterranean vegetation and soils. Shifts in historical wildfire regimes have been observed in all European Mediterranean regions (Pausas et 
al., 2004; Curt et al., 2009). Since the 1970s, the abandonment of agricultural lands and the increase in human population and activities have resulted in a dramatic increase in number and size of fires, and thus locally in fire frequency. Recurrent wildfires, through erosion and repeated burnings, may progressively impoverish soil especially in terms of organic matter and nutrients (Reich et al., 2001; Knicker, 2007) to such a point that soil microbial properties may be durably altered. Despite abundant research on vegetation dynamics following fire, as well as on immediate post-fire changes in the chemical and microbiological properties of soils, little is known about the impact of recurrent wildfires on soil microbial recovery, and driving factors remain uncertain. Because, soil microbial communities are responsible for the conversion of organic matter into plant available nutrients (Wardle, 1998), increase in fire frequency and shorter periods for recovery of microbial mineralising activities, may lead to reduction in site productivity and to loss of ecosystem resilience in the long term. A better understanding of mechanisms underlying recovery of soil properties after fire can have direct implications in choice of land management options (Scheffer and Carpenter, 2003).

High soil temperature during fire has a temporary sterilising effect on soil (DeBano et al., 1998) resulting in immediate decrease in microbial biomass, basal respiration, enzyme activities, catabolic diversity and nitrogen mineralisation (Hernández et al., 1997; Ajwa et al., 1999; Boerner and Brinkman, 2003; D’Ascoli et al., 2005). In the same time, intense fires cause significant loss of organic matter and marked alterations in functional organic groups (Knicker et al., 2005), such as a removal of external oxygen groups, a reduction in the chain length of alkyl compounds, a conversion of amide- $\mathrm{N}$ into heterocyclic- $\mathrm{N}$ compounds, and a macromolecular condensation of humic substances (González-Pérez et al., 2004). Mineral $\mathrm{N}\left(\mathrm{NO}_{3}{ }^{-} \mathrm{N}\right.$ and $\mathrm{NH}_{4}{ }^{+}-\mathrm{N}$ ) content tends to immediately increase in the soil surface after burning (Wan et al., 2001). Both $\mathrm{NH}_{4}{ }^{+}-\mathrm{N}$ and $\mathrm{NO}_{3}{ }^{-}-\mathrm{N}$ pulses are however rapidly dissipated through plant assimilation and microbial activities (i.e. immobilisation for both $\mathrm{NH}_{4}{ }^{+}-\mathrm{N}$ and $\mathrm{NO}_{3}{ }^{-} \mathrm{N}$ and nitrification), leaching, surface runoff and erosion (Wondzell et al., 2003). The ability of soil microbial communities and their activities to recover from disturbance depends primarily on nutrient availability (Moore et al., 1993), $\mathrm{pH}$ (Wardle, 1998) and on soil organic matter remaining after disturbance or brought to soil by vegetation (Gros et al., 2004). Hart et al. (2005) suggested that, where frequent fires have shaped the evolutionary history of a forest, the recovery of soil microbial properties is mediated primarily by fire-induced changes in plant community. In these conditions the quantity and quality of soil resources are expected to be primary driving factors by which the vegetation influences soil microbial recovery. However, these driving factors remains inaccurate and few studies focused on the relationships between the soil resource and the microbial recovery after frequent wildfires over long term.

The two main objectives of this study were (1) to determine short term and long term recoveries of soil chemical properties and microbial mineralising activities in both infrequently and frequently burned sites, and (2) to determine if/how changes in microbial activities are correlated with fire-induced changes in soil chemical properties. For these purposes, soils from 17 plots across the Mediterranean region in the southeastern of France, with similar environmental characteristics, but different wildfire regimes (frequently vs infrequently burned), were analysed for organic and inorganic nutrient content and chemical functional groups of SOM using FT-MIR spectroscopy. All the microbial activities measured in these soils (i.e. net $\mathrm{N}$-mineralisation, diverse $\mathrm{C}$ substrate utilisation capabilities and enzymes activities) are involved in organic matter 
mineralisation and thus in dynamic of $\mathrm{C}, \mathrm{N}$ and $\mathrm{P}$. Soil properties were measured 4 and 17 years after the last fire and compared to an unburned soil since at least 57 years. We hypothesised that the frequent wildfire regime would cause a lasting increase in most recalcitrant organic matter forms resulting in changes of microbial catabolic capabilities and in a slowdown of mineralising activities. Moreover, decrease in such microbial mineralising activities was hypothesised to affect recovery of soil nutrient content.

\section{Materials and methods}

\subsection{Study area, wildfire history and soil sampling}

The study was conducted in the south-eastern area of the Maures mountain range (Var, France, $43^{\circ} 20^{\prime} \mathrm{N}$ and $6^{\circ} 37^{\prime} \mathrm{E}$ ). The study area $\left(90 \mathrm{~km}^{2}\right)$ is characterised by a Mediterranean climate with dry, hot summers and wet and temperate winters. The mean annual precipitation is $920 \mathrm{~mm}$ (1962-2003). A persistent drought was recorded during the 2003-2007 period (640 mm per year) with a dramatic drop in 2007 (430 mm), the year of soil sampling. The average monthly temperature varies from $7^{\circ} \mathrm{C}$ in January to $22^{\circ} \mathrm{C}$ in July, with mean annual temperatures close to $14^{\circ} \mathrm{C}$. Regarding vegetation, at the early stage of succession (i.e. following forest fires), plant communities are dominated by herbaceous and fast growing species such as Cistus monspeliensis L., Calycotome spinosa L., Erica arborea L. and Quercus suber L. At the later successional stage (i.e. with no fire for at least 57 years), closed forests are dominated by a tree stratum of Quercus suber L., Quercus ilex L. and Pinus pinaster Aiton subsp. pinaster.

Burned areas were mapped using a series of aerial pictures spanning a 57-years period from 1950 to 2007 and public fire databases. This mapping allowed us to reconstitute the history of the wildfire regimes for both frequent and infrequent regimes over this 57-years period. Soil samples were collected at 17 different sampling sites (300-400 $\mathrm{m}^{2}$ in size) (Table I) in order to represent 5 different burning histories, or wildfire regimes. The dates of each wildfire for the five regimes were reported in Table I. These wildfire regimes included 5 independent sites not burned at least since 1950 (NB-57yrs); 3 independent sites infrequently burned (1-2 wildfires) with the last wildfire in 1990 or 1982 (IB-17yrs); 3 independent sites frequently burned (4 wildfires) with the last wildfire in 1990 (FB-17yrs); 3 independent sites infrequently burned (2 wildfires) with the last wildfire in 2003 (IB-4yrs); and finally 3 independent sites frequently burned (4 wildfires) with the last wildfire in 2003 (FB-4yrs). Soils of these sites are mainly shallow alterites $(10-30 \mathrm{~cm})$ and were developed on a migmatitic gneiss (crystalline siliceous rock) as parent rock. Soil pH is around 6-6.5. Unburned sites present A (B) CR profile and they can be classified as Dystric Cambisol (WRB classification). Under a thick litter $(1-3 \mathrm{~cm})$, the A horizon, $5 \mathrm{~cm}$ thick, is characterized by a brown colour due to organic matter and a low content of coarse fragments (1030\%). For burned soils, classified as Dystric Leptosol, only A and CR horizons are present. The other differences with the unburned soils are that the A horizon is clearer and that the transition from CR horizon to parent rock is faster. Moreover, these sites present similar exposition (SE-SW), slope (10-40\%), altitude (60-360 a.s.1.) and forest type (i.e. cork oak being common to all areas). Thus in this work, we may consider that fire frequency was the only influencing factor. Dominant plant species and soil type of each wildfire regime are reported in Table I. 
Guénon et al. (2011). Land Degradation \& Development, DOI: 10.1002/ldr.1109

Table I: Wildfire regimes and associated vegetation structure and soil types

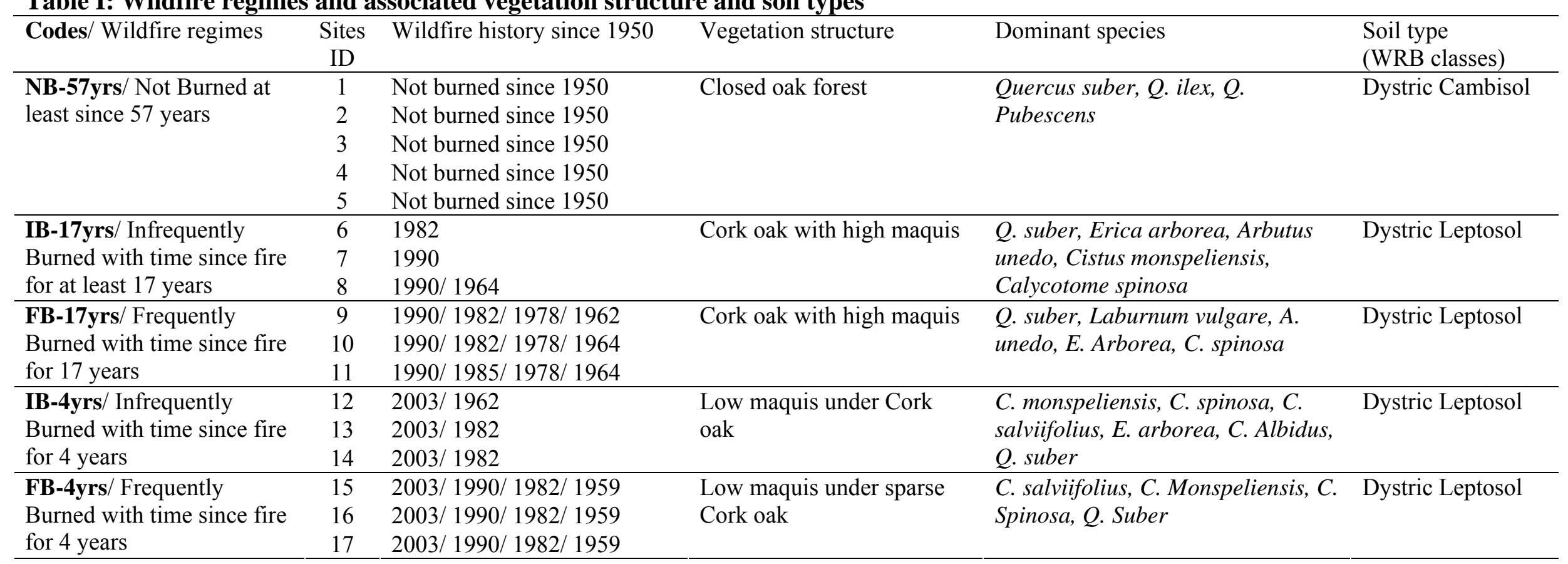

Table II: Soil nutrient contents

\begin{tabular}{|c|c|c|c|c|c|c|c|}
\hline & \multicolumn{2}{|c|}{ ANOVA test } & \multicolumn{5}{|c|}{ Wildfire regimes } \\
\hline & $\mathrm{F}$ & $\mathrm{p}$ & NB-57yrs & IB-17yrs & FB-17yrs & IB-4yrs & FB-4yrs \\
\hline Organic matter $(\%)$ & 4.21 & $<0.05$ & $8.5 \pm 1.9 \mathrm{~b}$ & $7.9 \pm 1.6 b$ & $8.9 \pm 1.2 b$ & $6.3 \pm 0.2 \mathrm{ab}$ & $4.9 \pm 0.8 \mathrm{a}$ \\
\hline Total organic $\mathrm{C}\left(\mathrm{g} \cdot \mathrm{kg}^{-1}\right)$ & ns & ns & $43.4 \pm 12.1$ & $45.37 \pm 13.6$ & $49.1 \pm 8.2$ & $34.6 \pm 2.3$ & $23.8 \pm 9.1$ \\
\hline Total N (g. $\left.\mathrm{kg}^{-1}\right)$ & ns & ns & $2.5 \pm 0.7$ & $2.2 \pm 0.7$ & $3.1 \pm 1.0$ & $2.3 \pm 0.6$ & $1.5 \pm 0.7$ \\
\hline $\mathrm{C} / \mathrm{N}$ ratio & ns & ns & $20.5 \pm 3.5$ & $21.5 \pm 6.2$ & $17.2 \pm 2.9$ & $17.1 \pm 4.9$ & $20.9 \pm 6.2$ \\
\hline $\mathrm{NH}_{4}{ }^{+}-\mathrm{N}\left(\mathrm{mg} \cdot \mathrm{kg}^{-1}\right)$ & ns & ns & $4.24 \pm 0.4$ & $4.09 \pm 1.4$ & $5.27 \pm 2.9$ & $3.65 \pm 1.4$ & $3.38 \pm 0.6$ \\
\hline $\mathrm{NO}_{3}{ }^{-}-\mathrm{N}\left(\mathrm{mg} \cdot \mathrm{kg}^{-1}\right)$ & 5.84 & $<0.01$ & $9.7 \pm 5.1 \mathrm{~b}$ & $0.7 \pm 0.4 \mathrm{a}$ & $11.2 \pm 6.0 \mathrm{~b}$ & $0.5 \pm 0.1 \mathrm{a}$ & $0.7 \pm 0.8 \mathrm{a}$ \\
\hline $\mathrm{PO}_{4}{ }^{3-}-\mathrm{P}\left(\mathrm{mg} \cdot \mathrm{kg}^{-1}\right)$ & ns & ns & $86.0 \pm 37.0$ & $89.0 \pm 63.0$ & $164.0 \pm 65.0$ & $304.0 \pm 224$ & $137.0 \pm 44.0$ \\
\hline
\end{tabular}

Mean values ( \pm standard deviation) followed by the same letters were not significantly different at $\mathrm{P}<0.05$ (LSD), ns: no significant ANOVA test at $\mathrm{P}=0.05$. 
For each of the three replicated sites, after removing the thin litter layer from the soil surface, five soil samples, each $20 \times 20 \mathrm{~cm}$ in size, were randomly cored in February 2007 from the A horizon ( 0 to $5 \mathrm{~cm}$ depth) and pooled to form one composite sample. The composite soil samples were sieved ( $2 \mathrm{~mm}$ mesh size) and homogeneously mixed. An aliquot was airdried. Back to the laboratory, soil samples were pre-incubated at $25^{\circ} \mathrm{C}$ and $60 \%$ of water holding capacity (WHC) for one week to obtain detectable microbial activities. All microbial and chemical properties were measured on these pre-incubated soils.

\subsection{Soil chemical and FT-MIR spectroscopic properties}

Soil total organic carbon (TOC) and total nitrogen (TN) content were measured on airdried samples using a $\mathrm{C} / \mathrm{N}$ elemental analyzer (Flash EA 1112 series ThermoScientific). Soil organic matter content was obtained by loss on ignition $\left(16 \mathrm{~h}, 550^{\circ} \mathrm{C}\right)$. Inorganic-N forms $\left(\mathrm{NH}_{4}{ }^{+}-\mathrm{N}\right.$ and $\left.\mathrm{NO}_{3}{ }^{-} \mathrm{N}\right)$ were extracted and analysed as described below. Available phosphorus $\left(\mathrm{PO}_{4}{ }^{3-}-\mathrm{P}\right)$ was extracted with $0.1 \mathrm{M}$ citric acid and subsequently measured colorimetrically using the French norm NF X31-160 (AFNOR, 1996).

Fourier Transform Mid Infrared (FT-MIR) spectroscopy was used to identify and quantify the presence of important organic functional groups in soil samples. Prior to FT-MIR analysis, soils were pre-treated with chlorhydric and fluorhydric acid according to the procedure of Gelinas et al. (2001). This pre-treatment removes metal oxides and silicate minerals which absorb in mid-infrared spectroscopy wavelengths (Johnston and Aochi, 1996), concentrates organic matter (Kogel-Knabner, 1997) and thus improves peaks resolution. Soils were freeze dried and then deposited on an attenuated total reflection (ATR) cell equipped with a diamond crystal. FT-MIR spectra were acquired using a Thermo Nicolet Avatar 370 spectrometer equipped with a DTGS detector, an Ever-Glo source and a $\mathrm{Kbr} /$ germanium beam-splitter. Five spectra per sample were recorded between $700 \mathrm{~cm}^{-1}$ and $4000 \mathrm{~cm}^{-1}$, the nominal resolution was $4 \mathrm{~cm}^{-1}$. For each spectrum, 64 scans were co-added. Air was taken as reference for the background spectrum before each sample. FT-MIR spectral data in the diamond interference region (2200-1900 $\mathrm{cm}^{-1}$ ) were excluded from analyses (Artz et al., 2008). Functional groups of soil organic matter were defined according to Haberhaueur et al. (1998), Artz et al. (2008) and Tinoco et al. (2006) and selected absorption peaks were integrated using the software Thermo Omnic 7.1 (Thermo Electron. Corp., Waltham, MA, USA). Ten absorption peaks were recorded at 2920, 2850, 1690, 1633, 1556, 1538, 1521, 1453, 1420, $1373 \mathrm{~cm}^{-1}$. The peaks at 2920 and $2850 \mathrm{~cm}^{-1}$ correspond, respectively, to asymmetric and symmetric $\mathrm{C}-\mathrm{H}$ vibrations of the $\mathrm{CH}_{2}$ group of aliphatic structures (e.g. wax, fats, and lipids). The shoulder at $1690 \mathrm{~cm}^{-1}$ represents $\mathrm{C}=\mathrm{O}$ vibrations of carboxylate. The broad peak at $1633 \mathrm{~cm}^{-1}$ can be assigned to both $\mathrm{C}=\mathrm{O}$ vibrations of carboxylate and $\mathrm{C}=\mathrm{C}$ vibrations of aromatic molecules. The peaks at 1556 and $1538 \mathrm{~cm}^{-1}$ can be attributed to both $\mathrm{N}-\mathrm{H}$ (amide II) and $\mathrm{C}=\mathrm{C}$ vibrations of aromatic molecules and $1521 \mathrm{~cm}^{-1}$ only to $\mathrm{N}-\mathrm{H}$ vibrations. The peaks recorded at 1373 and $1453 \mathrm{~cm}^{-1}$ correspond to aliphatic and phenolic $\mathrm{C}-\mathrm{H}$ deformations and the peak at $1420 \mathrm{~cm}^{-1}$ is due to symmetric $\mathrm{C}-\mathrm{O}$ stretching of carboxylate/carboxylic structures. Absorption peaks with overlapped mineral and organic assignments were removed from the analysis (i.e. peaks at 3690, 3620, 1161, 1010, 825 and $740 \mathrm{~cm}^{-1}$ ) (Haberhauer et al., 1998; Rumpel et al., 2006). The broad O-H band located at $3600-3000 \mathrm{~cm}^{-1}$ was not integrated, as the intensity of the $\mathrm{O}-\mathrm{H}$ band is influenced by water content and thus provides only limited information about soil organic matter composition (Kaiser and Ellerbrock, 2005). In order to determine relative changes in functional groups of soil organic matter, the relative absorbance ( $\mathrm{rA}$ ) of each peak was calculated by dividing the height of a selected peak by the sum of the heights of all peaks (e.g. $r A_{2920}=A_{2920} / \Sigma A_{(3310-}$ $1373 \mathrm{~cm}-1) \times 100)$. 


\subsection{Microbial biomass}

Microbial biomass (MB) was estimated using substrate-induced respiration (SIR) rates (Anderson and Domsch, 1978). Ten grams (dry weight equivalent) of sub-samples were placed in $117 \mathrm{ml}$ glass jars and amended with powdered glucose $\left(1000 \mu \mathrm{g} \mathrm{C} \mathrm{g}^{-1}\right.$ soil). One ml of air was sampled in the head space with a syringe and injected into a gas chromatograph (Chrompack CHROM 3 - CP 9001) equipped with a thermal conductivity detector and a packed column (Porapack) to analyse $\mathrm{CO}_{2}$ production. The $\mathrm{CO}_{2}$ concentration of flushed air was subtracted from $\mathrm{CO}_{2}$ concentrations of each samples and resulting values were adjusted to $22^{\circ} \mathrm{C}$ according to Ideal Gas Laws using a $\mathrm{Q}_{10}=2$. SIR rates were converted into MB using equations given by Beare et al. (1990).

\subsection{Net ammonification and nitrification}

Two sub-samples of $10 \mathrm{~g}$ (dry wt equiv.) of soil were weighed on two distinct $500 \mathrm{ml}$ glass jars. One of the sub-sample (referred as t0) was immediately analysed for inorganic-N $\left(\mathrm{NH}_{4}{ }^{+}-\mathrm{N}\right.$ and $\left.\mathrm{NO}_{3}{ }^{-}-\mathrm{N}\right)$ concentrations after extraction $(100 \mathrm{ml}, 1 \mathrm{M} \mathrm{KCl})$. Samples were shaken for $1 \mathrm{~h}$ on an orbital shaker then filtered through Whatman No. 5 cellulose filter. Filtrates were analysed colorimetrically for $\mathrm{NH}_{4}{ }^{+}-\mathrm{N}$ (nitroprusside-salicylate method) and $\mathrm{NO}_{3}{ }^{-} \mathrm{N}$ (nitrosalicylic acid method) (Mulvaney, 1996). The second sub-sample was incubated for 30 days at $25^{\circ} \mathrm{C}(\mathrm{t} 30)$ and inorganic-N forms were analysed as described above. During incubation, jars were periodically weighed and initial moisture content restored using a fine-mist spray. We defined net ammonification and net nitrification as the difference in $\mathrm{NH}_{4}{ }^{+}-\mathrm{N}$ and $\mathrm{NO}_{3}{ }^{-}-\mathrm{N}$ concentrations before and after the incubation $(\mathrm{t} 30-\mathrm{t} 0)$.

\subsection{Soil microbial C-substrate utilisation profiles and enzyme activities}

The diverse $\mathrm{C}$-substrate utilisation capabilities of cultivable microbial communities were determined with BIOLOG ${ }^{\circledR}$ EcoPlates (BIOLOG Inc., Hayward, CA) using a procedure adapted from Garland and Mills (1991). We purposely did not adjust the inoculum in order to obtain a uniform cell density as we considered the total microbial number as an inherent characteristic of microbial communities of each plot. Briefly, $5 \mathrm{~g}$ (dry weight equivalent) of sub-sample was added to $50 \mathrm{ml}$ of sterile $0.1 \%$ Na-pyrophosphate solution $(\mathrm{pH} \mathrm{7)}$. The mixture was then shaken on an orbital shaker for $20 \mathrm{~min}$, and centrifuged at $500 \mathrm{~g}$ for $10 \mathrm{~min}$ at $4{ }^{\circ} \mathrm{C}$ to obtain a microbial suspension. Exactly $1 \mathrm{ml}$ of supernatant was diluted into $99 \mathrm{ml}$ of sterile saline solution $(0.85 \% \mathrm{NaCl})$, hand-mixed for $30 \mathrm{sec}$. and left to stand for $10 \mathrm{~min}$. A $125 \mu \mathrm{l}$ aliquot of the diluted solution was added to each of 96 wells in a BIOLOG ${ }^{\circledR}$ EcoPlate. Plates were incubated at $25^{\circ} \mathrm{C}$ and colour formation in each well was monitored at monochromatic light $(595 \mathrm{~nm})$ absorbance using an Elisa 960 Metertech ${ }^{\circledR}$ spectrophotometer. Measurements were performed three times a day until average well colour development (AWCD) exceeded a value of 1.0 standardised absorbance units (i.e. 3-5 days incubation). The incubation time $\left(\mathrm{T}_{0.5}\right)$ corresponding to an $\mathrm{AWCD}=0.5$ absorbance unit was then determined for each triplicate set of a plate. Before statistical analyses, the absorbance value of each control well at $T_{0.5}$ was subtracted from absorbance values at $T_{0.5}$ of the 31 associated wells containing C-substrates.

Fluorescein diacetate hydrolase (FDAse) activity was assayed according to the modified method of Green et al. (2006). Four $\mathrm{ml}$ of $60 \mathrm{mM}$ potassium phosphate buffer ( $\mathrm{pH}$ 7.6) with $50 \mu \mathrm{l}$ of FDA solution ( $2 \mathrm{mg} / \mathrm{ml}$ of acetone) were added to $0.5 \mathrm{~g}$ of soil (fresh mass) and incubated at $30^{\circ} \mathrm{C}$ for one hour. The reaction was stopped by adding $2 \mathrm{ml}$ of acetone, and the mixture was immediately centrifuged for $2 \mathrm{~min}$ at $12000 \mathrm{~g}$. The fluorescein released from FDA was measured in the supernatant at $490 \mathrm{~nm}$.

$\beta$-glucosidase activity was assayed according to the modified method of Eivazi and Tabatabai (1988). Six $\mathrm{ml}$ of sodium acetate buffer $(0.1 \mathrm{M}, \mathrm{pH} 5)$ and $1 \mathrm{ml}$ of $5 \mathrm{mM}$ - 
nitrophenyl- $\beta$-glucopyranoside ( $p \mathrm{NPG}$ ) were added to $0.5 \mathrm{~g}$ of soil (fresh mass) and incubated $\left(1 \mathrm{~h}, 30{ }^{\circ} \mathrm{C}\right)$. The reaction was stopped and colour revealed by adding $1 \mathrm{ml}$ of $0.5 \mathrm{M} \mathrm{CaCl}_{2}$ and $4 \mathrm{ml}$ of $0.5 \mathrm{M} \mathrm{NaOH}$, overall mixed and immediately centrifuged for 2 min at $12000 \mathrm{~g}$. The amount of $p$-nitrophenol released from $p N P G$ was measured in the supernatant at 412 nm.

Activities of acid and alkaline phosphomonoesterases (AcP and AlP) were assayed according to the method of Tabatabai and Bremmer (1969). One $\mathrm{ml}$ of $p$-nitrophenyl phosphate ( $p$ NPP, $5 \mathrm{mM}$ ) was added to either $6 \mathrm{ml}$ of sodium acetate buffer for AcP $(0.1 \mathrm{M}$, $\mathrm{pH} 5.0)$ or glycine- $\mathrm{NaOH}$ buffer for AlP $(0.1 \mathrm{M}, \mathrm{pH} 9.0)$, thus added to $0.5 \mathrm{~g}$ of soil sample (fresh mass) and incubated $1 \mathrm{~h}$ at $30{ }^{\circ} \mathrm{C}$. The reaction was stopped and colour revealed by adding $1 \mathrm{ml}$ of $0.5 \mathrm{M} \mathrm{CaCl}_{2}$ and $4 \mathrm{ml}$ of $0.5 \mathrm{M} \mathrm{NaOH}$, overall mixed and immediately centrifuged for $2 \mathrm{~min}$ at $12000 \mathrm{~g}$. The amount of $p$-nitrophenol released from $p \mathrm{NPP}$ was measured in the supernatant at $412 \mathrm{~nm}$.

Phenol oxidase activity was assessed according to the modified method of Saiya-Cork et al. (2002). Six ml of $25 \mathrm{mM}$ L-DOPA solution (L-3,4-dihydroxyphenylalanine) in acetate buffer ( $50 \mathrm{mM}, \mathrm{pH} 6.5$ ) were added to $0.5 \mathrm{~g}$ of soil (fresh mass), mixed and incubated for 15 min. in darkness at $25^{\circ} \mathrm{C}$. The mixture was centrifuged at $12000 \mathrm{~g}$ before measuring absorption at $590 \mathrm{~nm}$.

For all enzyme assays, no toluene was added to the mixture because of the short incubation times. Enzyme assays were performed in 3 replicates for each soil sample. A unit (U) of enzyme activity was defined as a $\mu$ mole of substrate hydrolysed or oxidised per $\mathrm{min}^{-1}$, and per $g$ of soil dry weight $\left(\mathrm{U} \mathrm{g}^{-1} \mathrm{DW}\right)$.

\subsection{Statistical analyses}

Effects of wildfire regimes on soil microbial biomass, net ammonification and nitrification, enzyme activities, TOC, TN and nutrients content, chemical functions of SOM (i.e. FT-MIR peaks) were assessed using analysis of variance (ANOVA). The least significant difference (LSD) test was used to determine which regimes were significantly different from one another. When necessary, data were transformed to meet the assumptions of normality and homogeneity of variances. These analyses were performed using Statistica 6.0.

Principal component analyses (PCA) were performed on the covariance matrix obtained from Biolog ${ }^{\circledR}$ data using Primer software v6 (Primer-E Ltd, UK). The PCA provided an ordination of the microbial C-substrate utilisation profiles, which were plotted in one and two dimensions respectively, based on scores for the first two principal components (PC). A correlation circle was computed for Biolog $₫$ data to understand the contribution of each C-substrate to the principal component axes. Effects of wildfire history on microbial Csubstrate utilisation profiles and differences between wildfire regimes were tested by main and pair-wise tests in PERMANOVA using Primer software v6 (Primer-E Ltd, UK). PERMANOVA is a routine for testing the response of many variables to one or more factors in an analysis of variance (ANOVA) experimental design in the basis of any resemblance measure, using permutation methods (Anderson et al., 2008). PERMANOVA eliminates the requirement of normal distribution that must be satisfied for the analysis of variance but which is not the case for many kinds of multivariate ecological data (Legendre and Anderson, 1999).

Pearson's correlations were used to test relationships between measured soil chemical properties (pH, TOC, TN and nutrients contents), chemical functions of SOM (i.e. FT-MIR peaks) and enzyme activities. Co-inertia analyses (CIA) were computed to highlight the possible relationships between microbial C-substrate utilisation profiles and soil chemical properties or chemical functions of SOM. CIA is a multivariate analysis technique that enables a description of the relationships between two data tables (Dray et al., 2003). CIA can 
be used even if the number of rows (i.e. sampling sites) is lower than the number of columns (i.e. measured variables), which is the case in this paper. C-substrate utilisation profiles, chemical properties and chemical functions of SOM were firstly analysed by PCA. Separates PCAs find axes maximising inertia in each data tables. Then CIA ordinates the wildfire regimes for both co-structures on a single factorial map defined by the two first co-inertia axes. Another factorial map was drawn to show the contribution of soil chemical properties or chemical functions of SOM (i.e. FT-MIR peaks) to the co-inertia axes and thus to interpret the wildfire regime ordinations. To assess the significance of the CIA results, a Monte-Carlo permutation test was computed on the RV coefficient. This procedure tests the link between two tables by permuting simultaneously the rows of both tables. Computations were made with the free software $\mathrm{R}$ version 2.6.2 (R Development Core Team, 2007).

\section{Results}

\subsection{Wildfire regime effects on recovery of soil chemical properties}

Total organic carbon (TOC) and total nitrogen (TN) content, as well as $\mathrm{P}_{4}{ }^{3-}-\mathrm{P}$ content were not significantly related to wildfire regimes (Table II). The $\mathrm{C} / \mathrm{N}$ ratio was relatively constant and higher than 17 for all wildfire regimes. Wildfire regimes had variable effects on soil organic matter content (SOM) and $\mathrm{NO}_{3}{ }^{-}-\mathrm{N}$ content. SOM content was found significantly lower (ANOVA, $\mathrm{P}<0.05$ ) in soils four years after frequent wildfires (FB-4yrs) than in soils unburned since at least 57 years (NB-57yrs) (Table II). SOM content completely recovered seventeen years after frequent wildfires (FB-17yrs). Nitrate content in frequently and infrequently burned soils were significantly lower than those of soil which had not burned for 57 years (Table II). Seventeen years after infrequent wildfires (IB-17yrs), nitrate content was significantly lower than in NB-57yrs and FB-17yrs.

Relative intensities of FT-MIR peaks are shown in Table III. The two main peaks at 2920 (asymmetric $\mathrm{C}-\mathrm{H}$ bonds) and $1633 \mathrm{~cm}^{-1}(\mathrm{C}=\mathrm{C}$ and $\mathrm{C}-\mathrm{O}$ bonds) showed a high cumulative relative intensity of at least $56 \%$ (FB-2003) rising to $69 \%$ (IB-1990) (Table III). Five peaks at 2920 (asymmetric $\mathrm{C}-\mathrm{H}$ bonds), 2850 (symmetric $\mathrm{C}-\mathrm{H}), 1556(\mathrm{~N}-\mathrm{H}), 1538(\mathrm{~N}-$ $\mathrm{H}$ and $\mathrm{C}=\mathrm{C})$ and $1453(\mathrm{C}-\mathrm{H}) \mathrm{cm}^{-1}$ were significantly affected by the studied wildfire regimes (ANOVA test, Table III). The relative absorbance of C-H bonds (i.e. 2920 and $2850 \mathrm{~cm}^{-1}$ ) of aliphatic structures (e.g. wax, fats, and lipids) increased from the recent wildfire regimes (IB4 yrs and FB-4yrs) to the older regimes (NB-57yrs, IB-17yrs and FB-17yrs). A significant difference between frequent and infrequent wildfire regimes was measured only for the peak at $2920 \mathrm{~cm}^{-1}$ (asymmetric C-H bonds) in samples where the last fire occurred in 2003. Significant decreases in the relative intensity of the peaks at $1556 \mathrm{~cm}^{-1}$ and $1538 \mathrm{~cm}^{-1}(\mathrm{~N}-\mathrm{H}$ and $\mathrm{C}=\mathrm{C}$ ) were observed from $\mathrm{FB}-4 \mathrm{yrs}$ to $\mathrm{FB}-17 \mathrm{yrs}$ whereas no significant difference in the relative intensity of these peaks was found between NB-57yrs, IB-17yrs and IB-4yrs. Concerning the peak at $1453 \mathrm{~cm}^{-1}(\mathrm{C}-\mathrm{H})$, we measured significant decrease between FB-4yrs and FB-17yrs. Significant differences were also found between IB-4yrs and FB-4yrs, and between IB-17yrs and FB-17yrs. 
Guénon et al. (2011). Land Degradation \& Development, DOI: 10.1002/ldr.1109

Table III: Mean relative intensities of the FT-MIR peaks

\begin{tabular}{|c|c|c|c|c|c|c|c|c|}
\hline \multirow[b]{2}{*}{ Wavenumbers $\left(\mathrm{cm}^{-1}\right)$} & \multirow[b]{2}{*}{ Assignments } & \multicolumn{2}{|c|}{ ANOVA test } & \multicolumn{5}{|c|}{ Wildfire regime } \\
\hline & & $\mathrm{F}$ & $\mathrm{p}$ & NB-57yrs & IB-17yrs & FB-17yrs & IB-4yrs & FB-4yrs \\
\hline 2850 & sym C-H & 6.5 & $<0.01$ & $7.4 \pm 1.1 \mathrm{c}$ & $6.4 \pm 2.6 \mathrm{bc}$ & $7.3 \pm 0.9 \mathrm{c}$ & $5.2 \pm 1.5 \mathrm{ab}$ & $4.0 \pm 0.4 \mathrm{a}$ \\
\hline 1633 & $\mathrm{C}=\mathrm{C}$ and $\mathrm{C}=\mathrm{O}$ & ns & ns & $38.2 \pm 1.7$ & $43.4 \pm 3.2$ & $42.4 \pm 4.4$ & $43.6 \pm 8.2$ & $39.9 \pm 1.0$ \\
\hline 1556 & $\mathrm{~N}-\mathrm{H}$ (amide II), $\mathrm{C}=\mathrm{C}$ & 3.1 & $<0.05$ & $4.0 \pm 1.0 \mathrm{a}$ & $4.3 \pm 0.2 \mathrm{a}$ & $3.0 \pm 2.4 \mathrm{a}$ & $5.1 \pm 3.4 \mathrm{ab}$ & $7.9 \pm 1.1 \mathrm{~b}$ \\
\hline 1538 & $\mathrm{~N}-\mathrm{H}$ (amide II), $\mathrm{C}=\mathrm{C}$ & 3.2 & $<0.05$ & $3.9 \pm 1.2 \mathrm{a}$ & $4.1 \pm 0.2 \mathrm{a}$ & $4.0 \pm 2.1 \mathrm{a}$ & $4.4 \pm 2.6 \mathrm{a}$ & $7.9 \pm 1.5 \mathrm{~b}$ \\
\hline 1420 & $\mathrm{C}-\mathrm{O}$ & ns & ns & $3.9 \pm 1.1$ & $3.5 \pm 0.4$ & $3.8 \pm 1.1$ & $3.8 \pm 0.8$ & $3.9 \pm 0.4$ \\
\hline 1373 & $\mathrm{C}-\mathrm{H}$ & $\mathrm{ns}$ & $\mathrm{ns}$ & $5.1 \pm 0.5$ & $5.7 \pm 0.6$ & $2.9 \pm 0.9$ & $4.4 \pm 0.5$ & $4.6 \pm 0.2$ \\
\hline
\end{tabular}

Mean values ( $\% \pm$ standard deviation) with the same letters were not significantly different at $\mathrm{P}<0.05$ (LSD), ns: no significant ANOVA test at $\mathrm{P}=0.05$. Asym: asymmetric, sym: symmetric. 


\subsection{Wildfire regime effects on recovery of soil microbial activities}

The net ammonification was not significantly related to wildfire regimes (Figure 1a). The net nitrification presented two different trends in recovery (Figure 1b). The net nitrification increased significantly from FB-4yrs to FB-17yrs. It remained significantly lower in FB-17yrs than in NB-57yrs (ANOVA, $\mathrm{P}<0.05$ ). Net $\mathrm{NO}_{3}{ }^{-} \mathrm{N}$ immobilisation was observed in IB-17yrs and significant net nitrification rates were measured between IB-17yrs and NB$57 \mathrm{yrs}$.

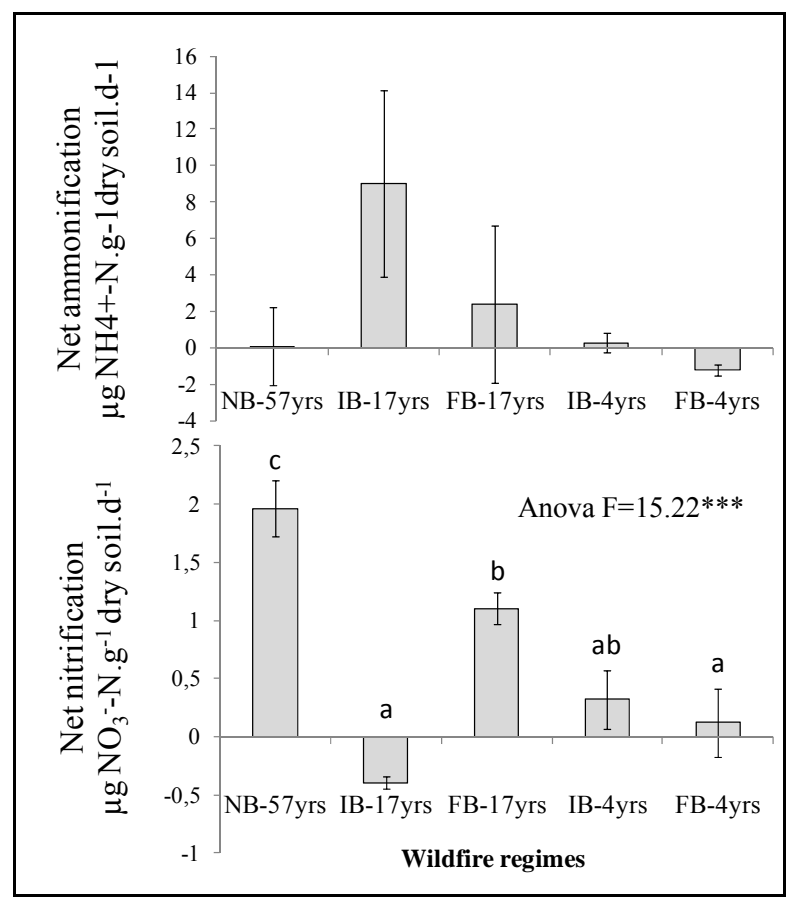

Figure 1: Net ammonification (a) and net nitrification (b) of not burned soils (NB-57yrs), infrequent (IB-4yrs and IB-17yrs) and frequent (FB-4yrs and FB-17yrs) wildfire regimes. Means with the same letters were not significantly different at $\mathrm{P}<0.05$ (LSD test); Vertical bars are standard deviations. $* * *$ indicate a significant ANOVA test at $\mathrm{P}<0.001$.

The C-substrate utilisation profiles were analysed by PCA. The first two principal components (PCs) (Figure 2a) accounted for 58\% of the total variance in the data, with PC1 accounting for $41.5 \%$ and PC2 for $16.5 \%$. PERMANOVA was used to test the differences between the wildfire regimes using the variance explained by the 31 axes of the PCA. IB$17 \mathrm{yrs}$, IB-4yrs and FB-4yrs were significantly discriminated from NB-57yrs (PERMANOVA pair-wise test; $\mathrm{P}<0.01$ ). The correlation circle (Figure $2 \mathrm{~b}$ ) showed that $11 \mathrm{C}$-substrates (i.e. arrows) were highly and positively correlated ( $r>0.5$ on PC1) to the ordination of IB-4yrs, FB$4 y$ rs and IB-17yrs. These $11 \mathrm{C}$-substrates are carboxylic acids, carbohydrates, amines, amino acids and polymers. Among these $11 \mathrm{C}$-substrates, five were N-containing substrates (i.e. LArginine, D-Glucosaminic acid, L-Asparagine, Putrescine and L-Serine) and 3 were complex substrates such as phenolic substrate highly used (i.e. 4-hydroxybenzoic acid) and 2 were polymers. In opposition, only $4 \mathrm{C}$-substrates were highly and positively correlated $(r>0.5$ on PC1) with the ordination of NB-57yrs and FB-17yrs which the three mostly used were substrates containing glucose-molecules (i.e. $\beta$-methyl-D-glucoside, glucose-1-phosphate, Dcellobiose). 

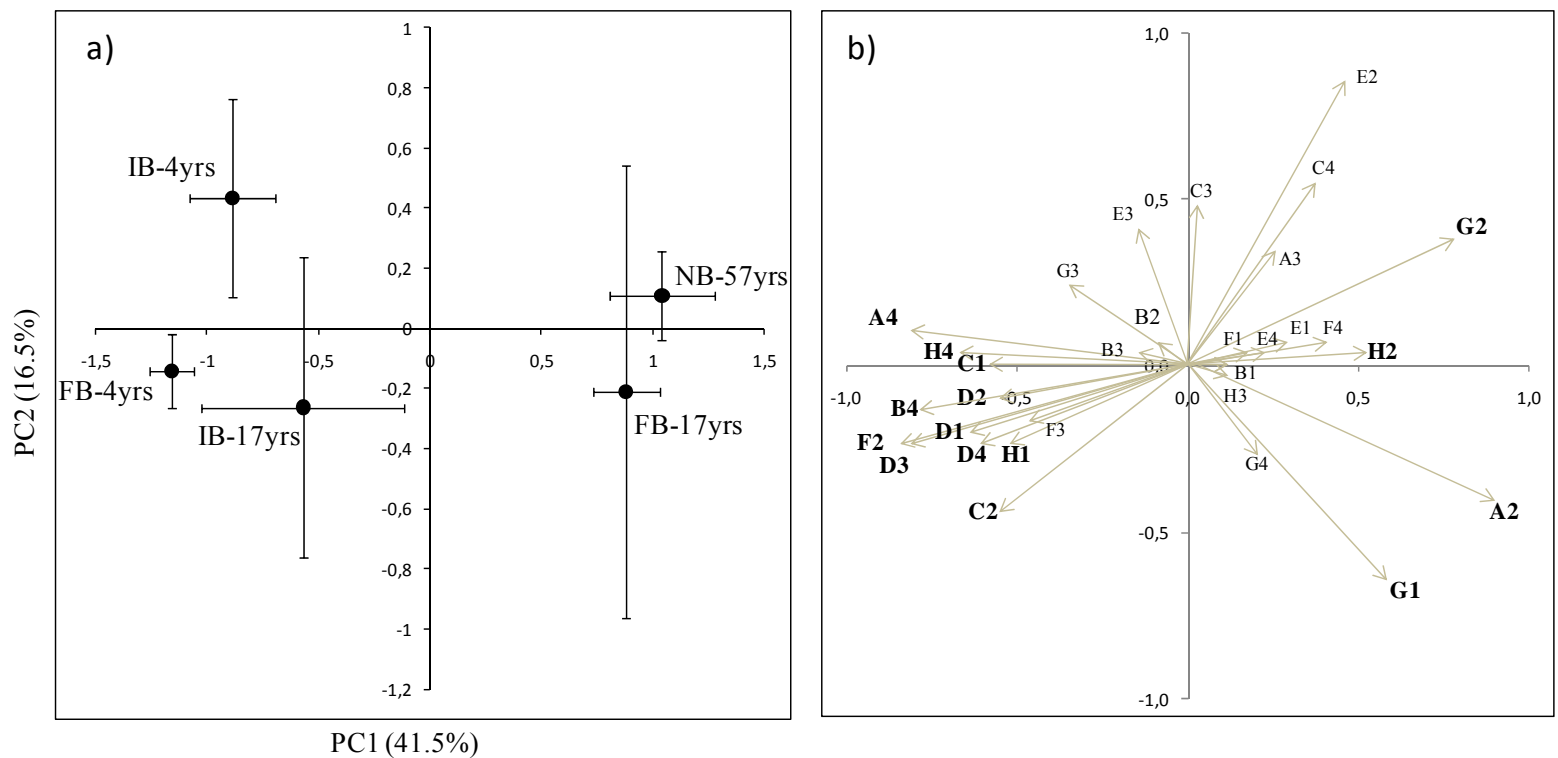

Figure 2: Factorial map $(\mathrm{PC} 1 \times \mathrm{PC} 2)(\mathrm{a})$ and correlation circle $(\mathrm{b})$ obtained from principal component analysis on microbial C-substrate utilisation profiles of not burned soils (NB57yrs), infrequent (IB-4yrs and IB-17yrs) and frequent (FB-4yrs and FB-17yrs) wildfire regimes. A2: $\beta$-methyl-D-glucoside ; A3: D-galactonic acid $\gamma$-lactone; A4: L-arginine; B1: pyruvic acid methyl ester; B2: D-xylose; B3: D-galacturonic acid; B4: L-asparagine; C1: tween 40; C2: i-erythritol; C3: 2-hydroxy benzoic acid; C4: L-phenylalanine; D1: tween 80; D2: D-mannitol; D3: 4-hydroxybenzoic acid; D4: L-Serine; E1: $\alpha$-cyclodextrin; E2: N-acetylD-glucosamine; E3: $\gamma$-hydroxybutyric acid ; E4: L-threonine; F1: glycogen; F2: Dglucosaminic acid; F3: itaconic acid; F4: glycyl-L-glutamic acid; G1: D-cellobiose; G2: glucose-1-phosphate; G3: $\alpha$-ketobutyric acid; G4: phenylethyl amine; H1: $\alpha$-D-lactose; H2: D,L $\alpha$-glycerol phosphate; H3: D-malic acid; H4: putrescine. Substrates in bold had correlation coefficient higher or equal to 0.5 . Bars represent standard errors.

Each enzyme activity had different trends in recovery after both wildfire regimes (Figure 3). FDAse activity was significantly higher $(\mathrm{P}<0.05)$ for FB-4yrs, IB-4yrs and FB17 yrs than NB-57yrs (Figure 3a). $\beta$-glucosidase activity was significantly higher for soils burned 4 years ago than those burned 17 or 57 years ago regardless the fire regime (Figure $3 b)$. Acid and alkaline phosphomonoesterase activities were both significantly lower for soils burned 4 years ago regardless the fire regime (Figure 3c). Phenol oxidase activity was significantly lower in frequently burned soils compared to NB-57 (Figure 3d).

There was no significant difference among infrequently and frequently burned soils for recovery of microbial biomass (Figure 4). A lower significant microbial biomass was measured for the soils burned in 2003 (IB-4yrs and FB-4yrs) compared to other regimes. No significant difference was measured between NB-57yrs and IB-17yrs or FB-17yrs. 


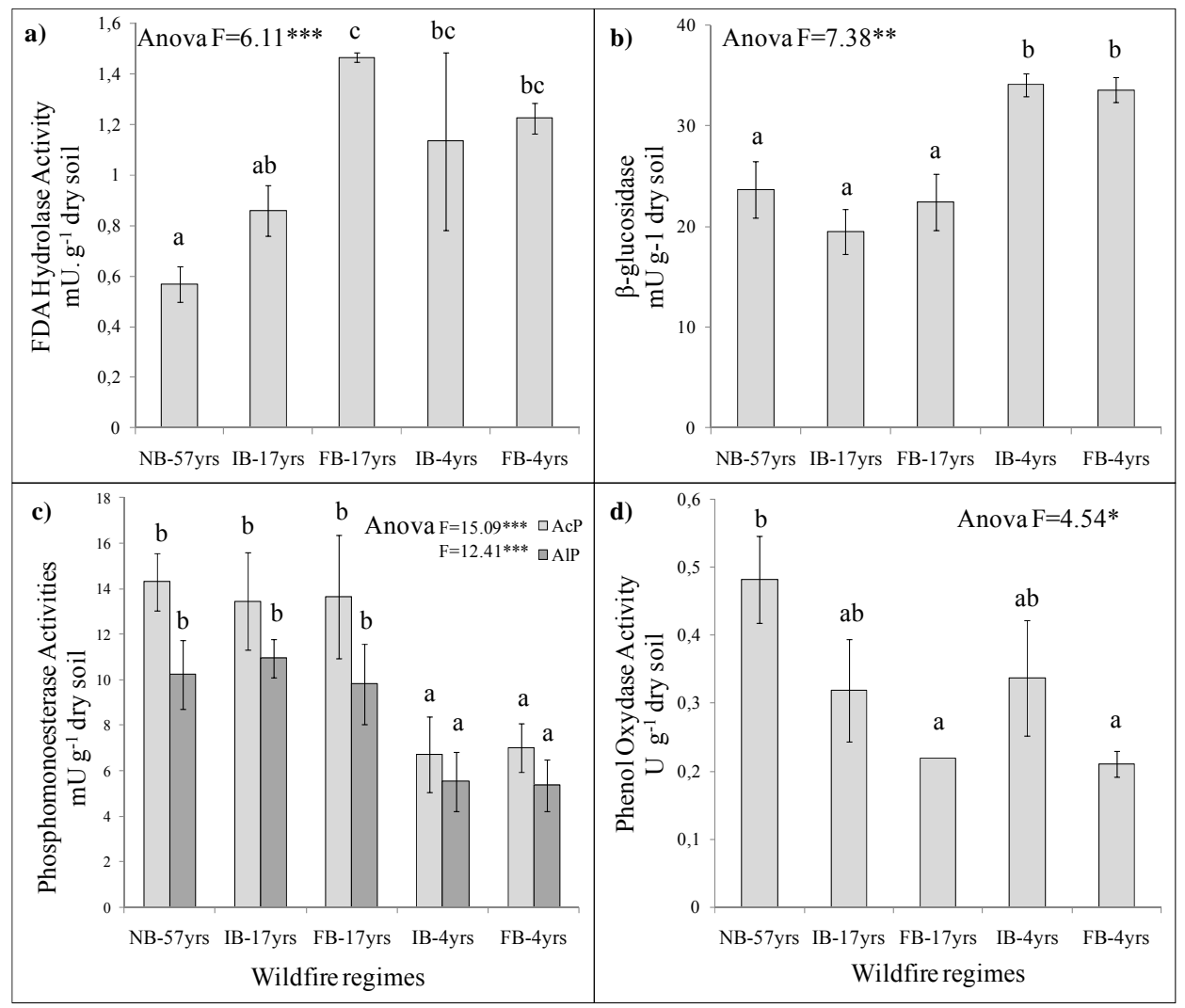

Figure 3: Activities of FDA hydrolase (a), $\beta$-glucosidase (b), acid (AcP) and alkaline (AlP) phosphomonoesterases (c), and phenol oxidase (d) of not burned soils (NB-57yrs), infrequent (IB-4yrs and IB-17yrs) and frequent (FB-4yrs and FB-17yrs) wildfire regimes. Means with the same letters were not significantly different at $\mathrm{P}<0.05$ (LSD test); vertical bars are standard deviations. $*, * *, * * *$ indicate a significant ANOVA test at respectively $\mathrm{P}<0.05$, $\mathrm{P}<0.01$ and $\mathrm{P}<0.001$.

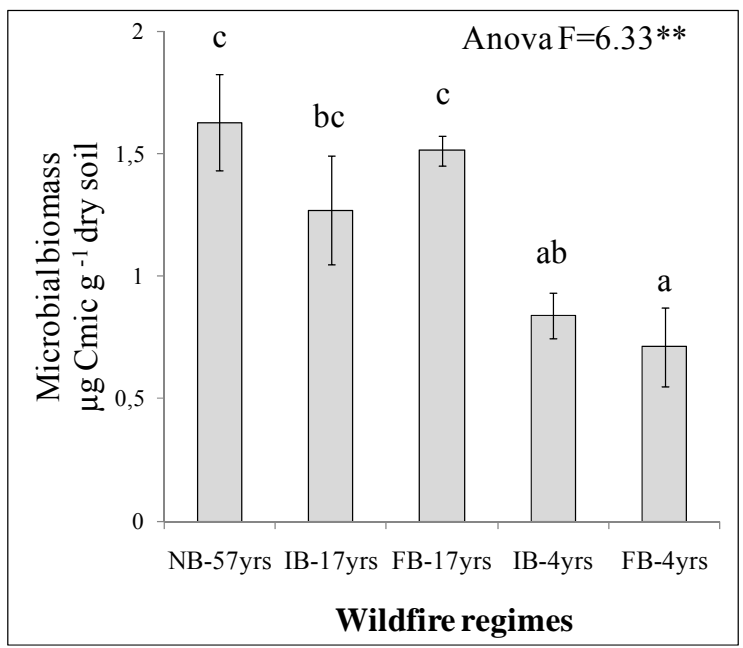

Figure 4: Microbial biomass of not burned soils (NB-57yrs), infrequent (IB-4yrs and IB$17 \mathrm{yrs}$ ) and frequent (FB-4yrs and FB-17yrs) wildfire regimes. Means with the same letters were not significantly different at $\mathrm{P}<0.05$ (LSD test); Vertical bars are standard deviations. ** indicate a significant ANOVA test at $\mathrm{P}<0.01$. 


\subsection{Relationships between soil microbial activities and chemical properties}

Relationships between C-substrate utilisation profiles (CLLPs) and soil chemical properties were tested by CIA. The Monte-Carlo permutation tests revealed an insignificant co-structure between $\mathrm{C}$-substrate utilisation profiles and nutrient contents $(\mathrm{RV}=0.42, \mathrm{P}=0.08)$, but significant co-structures between $\mathrm{C}$-substrate utilisation profiles and relative intensities of FT-MIR peaks $(\mathrm{RV}=0.44, \mathrm{P}<0.05)$. The first axis of the factorial map obtained from CIA between CLLPs and relative intensities of FT-MIR peaks (Figure 5a) explained $62.5 \%$ of the total co-inertia and the second axis accounted for $20.5 \%$. In the factorial map of this CIA, the C-substrate utilisation profiles of each wildfire regimes (black circles) were ordered on the first axis as follows: FB-4yrs, IB-4yrs, IB-17yrs, FB-17yrs, and NB-57yrs. The long arrows for infrequently burned soils (IB-4yrs and IB-17yrs) showed a weaker co-structure between CLPPs and FT-MIR peaks for these regimes. Moreover, the direction of these arrows (i.e. from the negative to the positive part of the map) indicated a recovery of the relative intensities of FT-MIR peaks for infrequently burned soils. The Figure $6 \mathrm{~b}$ showed that the chemical functions $\mathrm{N}-\mathrm{H}, \mathrm{C}=\mathrm{C}$ and $\mathrm{C}=\mathrm{O}$ (i.e. 1538, 1556 and $1690 \mathrm{~cm}^{-1}$ ) had the higher contribution to the negative part of the first axis. These chemical functions were thus correlated to the C-substrate utilisation profiles of FB-4yrs, IB-4yrs and IB-17yrs. In opposition, the $\mathrm{C}-\mathrm{H}$ functions of aliphatic structures (i.e. 2920 and $2850 \mathrm{~cm}^{-1}$ ) contributed the strongest in the positive part of the first axis. These chemical functions were positively correlated with the $\mathrm{C}$-substrate utilisation profiles of FB-17yrs and NB-57yrs.

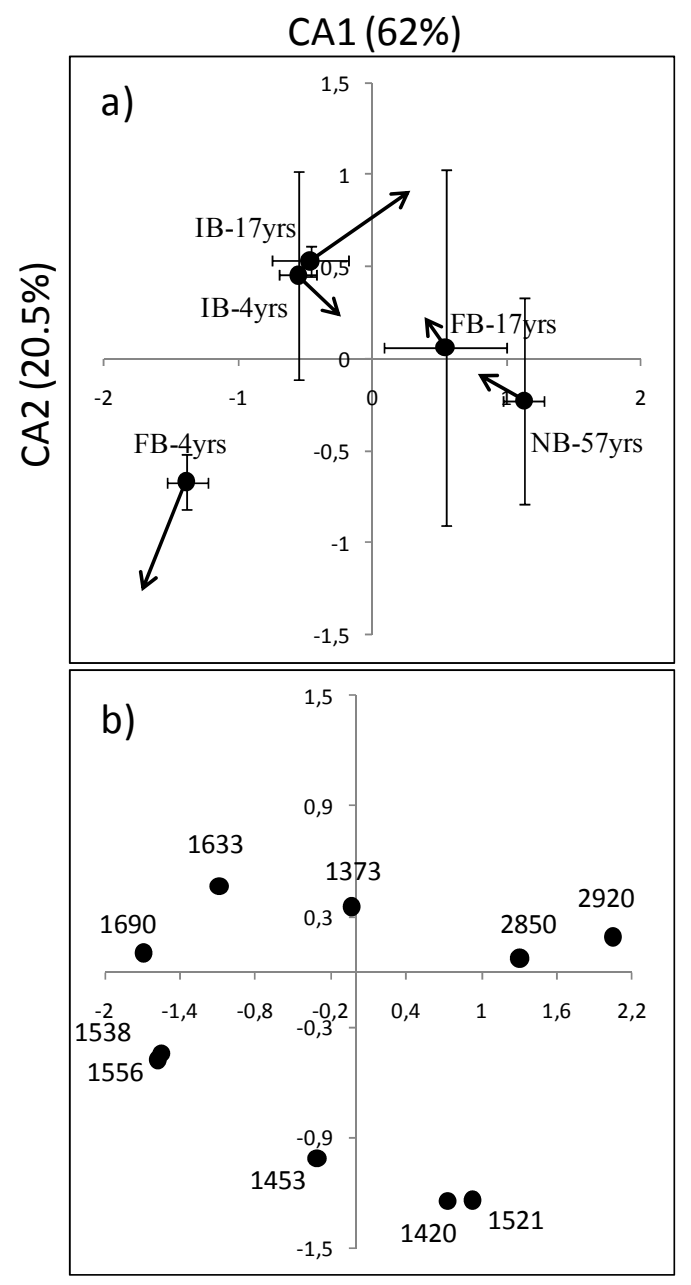

Figure 5: Factorial maps (a) and associated contributions to canonical axes (b) obtained from coinertia analysis between $\mathrm{C}$-substrate utilisation profiles and chemical functions of organic 
matter using FT-MIR. Treatments are not burned soils (NB-57yrs), infrequently (IB-4yrs and IB-17yrs) and frequently (FB-4yrs and FB-17yrs) burned soils. Bars represent standard errors. The head of arrows represent the ordination of FT-MIR data.

Relationships between soil chemical properties and microbial properties (i.e. FDAse, $\beta$ glucosidase, acid and alkaline phosphomonoesterases, and phenol oxidase, microbial biomass, net ammonification and net nitrification) were tested by Pearson's correlations. Results are shown in Table IV. The SOM content was positively correlated $(\mathrm{P}<0.05)$ to phosphomonoesterase activities, microbial biomass and net nitrification, and was negatively correlated $(\mathrm{P}<0.05)$ to the $\beta$-glucosidase activity. The relative intensity of $\mathrm{CH}_{2}$ groups of aliphatic structures was positively related $(\mathrm{P}<0.05)$ to phosphomonoesterase and phenol oxidase activities, microbial biomass and net nitrification, and negatively correlated $(\mathrm{P}<0.05)$ to both FDAse and $\beta$-glucosidase activities. In opposition, the high relative level of aromatic functions was negatively correlated $(\mathrm{P}<0.05)$ to all microbial properties excluding FDAse and $\beta$-glucosidase activities.

\section{Discussion}

\subsection{Recovery of soil chemical properties}

Four years after fires, the lasting low SOM content is in accordance with the results of Fernández et al. (1997), whereas other works have detected an increase in C content with low fire intensities (Santín et al., 2008; Knicker et al., 2005) due to input of partly charred material or litter from decaying trees. Seventeen years after fires, SOM content fully recovered whatever the wildfire regime.

FT-MIR was used for qualitative determination of particular functional groups in SOM. FT-MIR analysis showed that frequent wildfires slowed down the recovery of SOM spectroscopic properties at short term. The most significant changes in FT-MIR spectra were observed for the peaks at 1556 and $1538 \mathrm{~cm}^{-1}$, assigned to amide- $\mathrm{N}$ and aromatic chemical functions. Knicker et al. (2005) reported that fire resulted in an immediate enrichment of heterocyclic-N from amide-N. In our study, amide-N was not affected by fire (i.e. peak at $1521 \mathrm{~cm}^{-1}$ ) and thus the higher relative intensity of peaks at 1453,1556 and $1538 \mathrm{~cm}^{-1}$ in frequently and recently burned soils reveal an increased in proportion of aromatic and phenolic structures in SOM composition. Indeed, fire generally induce aromatisation of simple (sugars and lipids) (Tinoco et al., 2006) and complex compounds (humic substances) (Knicker et al., 2005) and production of black carbon from charred vegetation, litter or SOM (González-Pérez et al., 2004). In this study, frequent fires slowed down the recovery in SOM content indicated by lower SOM content for soils 4 years after the fire compared to soils 57 years after the last fire. Therefore, it is unlikely that the highest aromaticity after frequent fires resulted only from the aromatisation during the humification process of simple or complex compounds. Our results are in accordance with Santín et al. (2008) and suggest that the high relative intensity of aromatic structures resulted mainly from the incomplete combustion of the vegetation. Inputs of black carbon from charred plant material may have compensated a decrease in carbon contained in SOM resulting in the fast recovery of total soil organic carbon content (Table II). Moreover, in Mediterranean ecosystems, frequent wildfires lead to the establishment of shrub communities, which are often close to monospecific stands of Cistus sp. (Curt et al., 2009). In the Maures mountain ranges, Schaffhauser (2009) reported higher Cistus sp. coverage (86\%) four years after frequent fires than after infrequent fires $(45 \%)$. The litter of these species is characterised by high concentration of aromatic secondary metabolites (i.e. phenol, condensed tannins) and high lignin content (Castells et al., 2004). Large inputs of these aromatic compounds in soil through litter or root exudates could have 
contributed to the high degree of SOM aromaticity four years after frequent fires. Besides an increase in absorbance for the aromatic structures, the most profound decrease for all detected absorbance peaks was observed for asymmetric and symmetric stretching vibrations of methyl and methylene groups. A reduction of the relative abundance of long-chain alkanes and fatty acids is commonly observed and might be explained by possible thermal fragmentation of long-chain molecules (Almendros et al., 1988). At long term, FT-MIR analysis showed a relative increase of aliphatic structures, as expected with an increasing humification. The recovery of the relative intensity of aromatic structures during post-fire decomposition may result from their chemical and biochemical oxidation (Knicker et al., 2006) and from a loss of the black carbon through erosion process (Rumpel et al., 2006a; Rumpel et al., 2006b; Rumpel et al., 2009).

The effects of fire on soil nutrients depend on fire intensity (Marion et al., 1991; Neary et al., 1999; Reich et al., 2001), and on inorganic-N forms and location of nutrient pools (Carreira et al., 1996; Wan et al., 2001). Fire generally immediately increases ammonium $\left(\mathrm{NH}_{4}{ }^{+}-\mathrm{N}\right)$ content on soil surface due to combustion of organic matter and release of mineral $\mathrm{N}$ (Wan et al., 2001). Nitrate $\left(\mathrm{NO}_{3}{ }^{-} \mathrm{N}\right)$ can be formed some months after the fire as a result of nitrification (Covington and Sachett, 1992). These pulses can persist some years or can be rapidly dissipated through plant assimilation, microbial activities (i.e. immobilisation for both $\mathrm{NH}_{4}{ }^{+}-\mathrm{N}$ and $\mathrm{NO}_{3}{ }^{-}-\mathrm{N}$ and nitrification), strong surface runoff and erosion (Wondzell et al., 2003). Without difference in $\mathrm{NH}_{4}{ }^{+}-\mathrm{N}$ content, the low nitrate content four years after fire could be attributed to an important uptake by post-fire vegetation (Carreira and Niell, 1992) and a low net nitrification activity. The low microbial biomass, low total carbon content and strong changes in organic matter quality can explain the low net nitrification (Table IV) which was found to be carried out by heterotrophic microorganisms in Mediterranean ecosystems (Schimel et al., 1984). Phenolic compounds contained in Mediterranean post-fire vegetation such as Cistus sp. (Castells et al., 2004) are also known to increase $\mathrm{N}$-immobilisation (Schimel et al., 1996) and to decrease $\mathrm{NO}_{3}{ }^{-}-\mathrm{N}$ through allelopathic effects on nitrification (MacKenzie et al., 2006). 
Guénon et al. (2011). Land Degradation \& Development, DOI: 10.1002/ldr.1109

1 Table IV: Correlation coefficients ( $r$ values) between enzyme activities and soil chemical properties and relative intensities of FT-

2 MIR peaks

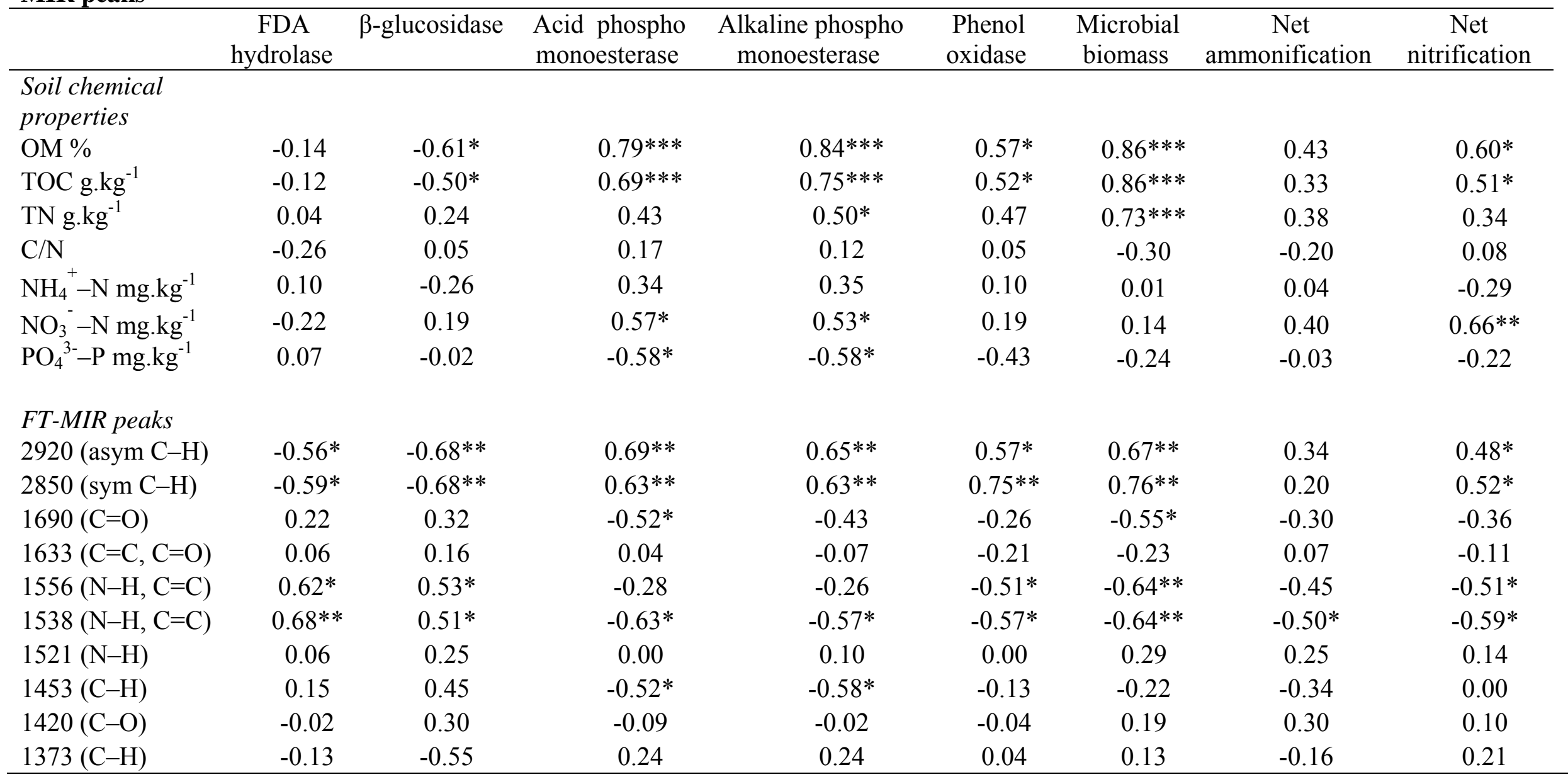

3 OM: organic matter, TOC: total organic carbon, TN: total nitrogen. *, **, *** indicate significance of linear regressions at $\mathrm{P}<0.05, \mathrm{P}<$

$4 \quad 0.01$ and $\mathrm{P}<0.001$ level respectively, n.s.: not significant. In all correlations, $\mathrm{n}=17$. 


\subsection{Recovery of soil microbial properties}

Frequent fires stimulated the net nitrification 17 years after the last fire (FB17yrs). Microbial biomass, organic matter content and quality completely recovered 17 years regardless the fire frequency (FB-17yrs and IB-17yrs, respectively) and thus, cannot explain difference in net nitrification between frequent and infrequent regimes. We suggest that frequently burned soils could contain more charcoal than infrequently burned soils. Charcoal adsorption of organic compounds is one possible mechanism which influences nitrification (DeLuca et al., 2006). Charcoal may have resulted in adsorption of phenolic compounds reducing the presence of factors inhibitory to nitrification (White, 1994) or may reduce the presence of C compounds that might otherwise stimulate immobilisation (Schimel et al., 1996). Moreover, establishment of dense plant covers 17 years after infrequent fire could lead to high plant uptake that would maintain nitrate content below to the unburned level.

Biolog ${ }^{\circledR}$ system was successful in differentiating soil samples based on Csubstrate utilisation profiles. In all soils which had not burned for at least 4 years, microbial communities used more intensively a great number of substrates reflecting a lower catabolic evenness. These substrates consisted in some N-containing and complex substrates such as aromatics and polymers. A change in C-substrate utilisation profiles was also found by D'Ascoli et al. (2005) after fire in Mediterranean region and was expected to result from changes in SOM quality. The strong co-structure between $\mathrm{C}$ substrate utilisation profiles and FT-MIR data (Figure 5) indicated that chemical functions of SOM, especially for recalcitrant forms such as aromatic, control the recovery of $\mathrm{C}$-substrate utilisation profiles. The low nitrate content in soils which had not burned for four years, concomitant with the high SOM aromaticity suggest an increase in microbial demand of nitrogen and preferential utilisation of N-containing compounds. Indeed, Orwin et al. (2005) reported that the addition of complex compounds to a grassland soil increased the use of $\mathrm{N}$-containing amino acids. They concluded that more enzymes were required for the decomposition of more complex $\mathrm{C}$ compounds, which resulted in greater microbial $\mathrm{N}$ demand. The weaker co-structure between C-substrate utilisation profiles and FT-MIR data in infrequently burned soils (IB-17yrs), suggest that chemical functions of SOM is less implicated in the recovery in C-substrate utilisation profiles at the long term. Surprisingly, 17 years after fire, Csubstrate utilisation profiles completely recovered only for frequently burned soils (FB$17 \mathrm{yrs})$. The complete recovery in net nitrification and thus in nitrate content could result in the decrease of $\mathrm{N}$-containing compound utilisation. This is consistent with Cookson et al. (2008) who found that the relative utilisation of amino acids tended to decrease when $\mathrm{NO}_{3}{ }^{-}-\mathrm{N}$ content increases.

Metabolic profiles obtained using the Biolog plates reflect only the potential of the culturable portion of the soil microbial community which responds to a various $\mathrm{C}$ substrate, whereas enzyme activities reflect the potential microbial metabolism in situ and are intrinsic parts of the dynamic of nutrient cycling. Our results showed, four years after fire, an increase in activities of both the FDAse and the substrate-specific $\beta$ glucosidase. FDAse activity is widely accepted as a measure of total soil microbial activity (Adam and Duncan, 2001). Indeed, FDA is a non-specific substrate used to assay hydrolytic activity of a broad range of hydrolases (e.g. esterases, proteases, lipases, cutinases). Previous studies have reported that fire generally decreases at short term many hydrolase activities such as deaminase, invertase, $\beta$-glucosidase and alkaline phosphomonoesterase (Ajwa et al., 1999; Boerner et al., 2000; Boerner and Brinkman, 
2003). Nutrient depletion, SOM alteration and microbial biomass loss after fire have been proposed to explain the decrease in hydrolase activities (Hernández et al., 1997). However, we showed that a decrease in microbial biomass is not necessarily accompanied by a comparable decrease in FDAse activity. $\beta$-Glucosidase which belongs to the pool of hydrolases is an enzyme involved in the enzymatic degradation of cellulose. It catalyses the cleavage of cellobiose and, therefore, regulates the supply of a high energy source for heterotrophic micro-organisms. The increase in $\beta$-Glucosidase is consistent with the findings of Fioretto et al. (2009) in early stages of post-fire chronosequence. Our study highlights that frequent burnings did not amplify this effect nor alter their recovery in the long term. However, the low microbial biomass alone could not be responsible for the high $\beta$-glucosidase activities after fire. According to Eivazi and Tabatabai (1988), $\beta$-glucosidases are produced not only by soil microorganisms but also by plants. High plant density measured in the first few years after fire in our sites (Curt et al., 2009) may be responsible for the high $\beta$-glucosidase activity. According to this trend, Garcia et al. (2002) showed a reduction in $\beta$ glucosidase activity attributed to a decline in plant cover density.

Acid and alkaline phosphomonoesterases are repressible hydrolases which reflect the specific phosphorus-demand of microbial biomass and plants (Chen et al., 2003). They are involved in the mineralisation of soil organic phosphorus. Seventeen years after infrequent and frequent fires, the complete recovery of soil organic matter content coupled with a probable strong microbial biomass demand may explain the recovery of these enzyme activities (Boerner and Brinkman, 2003). However, available phosphorus was not affected by wildfire regimes. This result could indicate either an immediate sequestration of phosphorus to Al-Fe oxides in acid soils (Certini, 2005) or high plant uptake (Saura-Mas and Lloret, 2009).

Phenol oxidase activity was lower four years and seventeen years in frequently burned soils. Artz et al. (2009) have shown a similar decrease of this activity after fire. This is in opposition with the hypothesis that fire, by decreasing total available $\mathrm{N}$ and easily decomposable C-sources (i.e. aliphatic structures), would increase the activity of phenol oxidase implicated in decomposition of SOM recalcitrant fractions (Boerner and Brinkman, 2003). Allison and Vitousek (2005) suggested that resource limitation can affect microbial enzyme production. Moreover, Sinsabaugh et al. (1993) found that phenol oxidase activities are primarily regulated by substrate availability. However, the persistent low phenol oxidase activity after frequent fires cannot be explained only by the resource depletion after fire. In our study, this enzyme activity completely recovered 4 years after infrequent fire regime whereas a decrease in resource availability (i.e. SOM and nitrate contents, relative absorbance of $\mathrm{C}-\mathrm{H}$ bonds of aliphatic structures) was observed. Fungi are known to be more sensitive to fire than bacteria (Pietikäinen and Fritze, 1995) and less resilient (Hamman et al., 2007). Moreover, they are the main producers of phenol oxidase enzymes (Baldrian, 2006). Frequent fires may have changed the composition (Artz et al., 2009) and biomass (Campbell et al., 2008) of fungi community resulting in a decrease of phenol oxidase activity. Measurement of enzyme activities, especially for phenol oxidase show great spatio-temporal variation (Sinsabaugh, 2009) and our results should be completed by the study of the seasonal and spatial variations of microbial recovery. 


\section{Conclusion}

In the current context of increase in the number and size of wildfires in all Mediterranean regions, forest management requires an effective assessment of the recovery of soil biological and chemical quality after frequent fires. We have attempted to assess short-term and long-term recoveries of soil chemical and microbial properties in both infrequently and frequently burned sites by sampling soils along a chronosequence of time-since-fire. Our results demonstrate that frequent wildfires slowed down recovery at short term of SOM quality and nutrient availability, probably mediated by dense coverage of shrubland species. Both low quantity and low quality (i.e. high percentage of aromatic and phenolic organic forms) of soil organic matter were found to be primary limiting factors of the soil microbial recovery four years after fire. Our study has showed that frequent wildfires can allow recovery of net nitrification and nitrate content, resulting in a recovery of C-substrate utilisation capabilities of microbial communities at long term. However, frequent wildfires slowed down the recovery of hydrolytic enzyme pool (i.e. FDA hydrolases) and phenol oxidase activity, both involved in soil $\mathrm{C}$ dynamic. Results from this study suggest therefore that 4 fires in 50 years is a fire frequency threshold beyond which soil quality and its services may be endangered. The soil microbial mineralizing activities both control and are controlled by soil chemical properties that are subject to change with fire frequency and post-fire vegetation (Hart et al, 2005). Integrating soil microbial data with vegetation patterns in further studies will therefore help us estimate vulnerability to frequent wildfires of fireprone ecosystems. Moreover, an enrichment of soil with labile organic matter could be a valuable rehabilitation technique to improve soil resource availability, restore microbial properties at short term and avoid the effects of frequent wildfires at long term.

\section{Acknowledgements}

This study was part of the IRISE project (http://irise.mediasfrance.org/) funded by the European Union, Forest Focus Regulation (No 2152/2003), the French Ministry of Agriculture and Fisheries and ECCOREV Research Federation. Financial support to R. Guénon was provided by the French Agency for Environment and Energy Management (ADEME) and Region Provence-Alpes-Côte d'Azur. Authors are grateful to F. Ruaudel, M. Carrara, A. Bourguiba for their technical assistance. We are very grateful to Mrs. M. Sweetko and M.-L. Guénon for their helpful assistance in English language.

\section{References}

Adam G, Duncan H. 2001. Development of a sensitive and rapid method for the measurement of total microbial activity using fluorescein diacetate (FDA) in a range of soils. Soil Biology and Biochemistry 33: 943-951.

Aerts R. 1995. The advantages of being evergreen. Trends in Ecology and Evolution 10: $402-407$.

AFNOR. 1996. Qualité des sols. Recueil des normes françaises. Association française de normalisation, Paris. 534 p.

Ajwa HA, Dell CJ, Rice CW. 1999. Changes in enzyme activities and microbial biomass of tallgrass prairie soil as related to burning and nitrogen fertilization. Soil Biology and Biochemistry 31: 769-777. 
Allison SD, Vitousek PM. 2005. Responses of extracellular enzymes to simple and complex nutrient inputs. Soil Biology and Biochemistry 37: 937-944.

Almendros G, Martin F, González-Vila FJ. 1988. Effects of fire on humic and lipid fractions in a Dystric Xerochrept in Spain. Geoderma 42:115-127.

Anderson JPE, Domsch KH. 1978. A physiological method for the quantitative measurement of microbial biomass in soils. Soil Biology and Biochemistry 10: 215-221.

Anderson MJ, Gorley RN, Clarke KR. 2008. PERMANOVA+ for PRIMER : guid to software and statistical methods. PRIMER-R: Plymouth, UK.

Artz RRE, Chapman SJ, Robertson AHJ, Potts JM, Laggoun-Defarge F, Gogo S, Comont L, Disnar JR, Francez AJ. 2008. FTIR spectroscopy can be used as a screening tool for organic matter quality in regenerating cutover peatlands. Soil Biology and Biochemistry 40: 515-527.

Artz RRE, Reid E, Anderson IC, Campbell CD, Cairney JWG. 2009. Long term repeated prescribed burning increases evenness in the basidiomycete laccase gene pool in forest soils. FEMS Microbiology Ecology 67: 397-410.

Baldrian P. 2006. Fungal laccases - occurrence and properties. FEMS Microbiology Reviews 30: 215-242.

Beare MH, Neely CL, Coleman DC, Hargrove WL. 1990. A substrate-induced respiration (SIR) method for measurement of fungal and bacterial biomass on plant residues. Soil Biology and Biochemistry 22: 585-594.

Boerner REJ, Decker KLM, Sutherland EK. 2000. Prescribed burning effects on soil enzyme activity in a southern Ohio hardwood forest: a landscape-scale analysis. Soil Biology and Biochemistry 32: 899-908.

Boerner REJ, Brinkman JA. 2003. Fire frequency and soil enzyme activity in southern Ohio oak-hickory forests, Applied Soil Ecology 23: 137-146.

Carreira JA, Arevalo JR, Niell FX. 1996. Soil degradation and nutrient availability in fire-prone Mediterranean shrublands of southestern Spain. Arid Soil Research and Rehabilitation 10: 53-64.

Carreira JA, Niell FX. 1992. Plant nutrient changes in a semi-arid Mediterranean shrubland after fire. Journal of Vegetation Science 3: 457-466.

Castells E, Penuelas J, Valentine DW. 2004. Are phenolic compounds released from the Mediterranean shrub Cistus albidus responsible for changes in $\mathrm{N}$ cycling in siliceous and calcareous soils? New Phytologist 162: 187-195. 
Certini G. 2005. Effects of fire on properties of forest soils: a review. Oecologia 143: 110.

Chen CR, Condron LM, Davis MR, Sherlock RR. 2003. Seasonal changes in soil phosphorus and associated microbial properties under adjacent grassland and forest in New Zealand. Forest Ecology and Management 177: 539-557.

Cookson WR, Murphy DV, Roper MM. 2008. Characterizing the relationships between soil organic matter components and microbial function and composition along a tillage disturbance gradient. Soil Biology and Biochemistry 40: 763-777.

Covington WW, Sackett SS. 1992. Soil mineral nitrogen changes following prescribed burning in ponderosa pine. Forest Ecology and Management 54: 175-191.

Curt T, Adra W, Borgniet L. 2009. Fire-driven oak regeneration in French Mediterranean ecosystems. Forest Ecology and Management 258: 2127-2135.

D’Ascoli R, Rutigliano FA, De Pascale RA, Gentile A, Virzo De Santo A. 2005. Functional diversity of the microbial community in Mediterranean maquis soils as affected by fires. International Journal of Wildland Fire 14: 355-363.

DeBano LF, Neary DG, Folliott PF. 1998. Fire's effects on ecosystems. New York: John Wiley and Sons, Inc. 333p.

DeLuca TH, MacKenzie MD, Gundale M J, Holben WE. 2006. Wildfire-produced charcoal directly influences nitrogen cycling in Ponderosa pine forests. Soil Science Society of America Journal 70: 448-453.

Dray S, Chessel D, Thioulouse J. 2003. Co-inertia analysis and the linking of ecological data tables. Ecology 84: 3078-3089.

Eivazi F, Tabatabai MA. 1988. Glucosidases and galactosidases in soils. Soil Biology and Biochemistry 20: 601-606.

Fernández I, Cabaneiro A, Carballas T. 1997. Organic matter changes immediately after a wildfire in an Atlantic forest soil and comparison with laboratory soil heating. Soil Biology and Biochemistry 29: 1-11.

Fioretto A, Papa S, Pellegrino A, Ferrigno A. 2009. Microbial activities in soils of a Mediterranean ecosystem in different successional stages. Soil Biology and Biochemistry 41: 2061-2068.

Garcia C, Hernandez T, Roldan A, Martin A. 2002. Effect of plant cover decline on chemical and microbiological parameters under Mediterranean climate. Soil Biology and Biochemistry 34: 635-642. 
Garland JL, Mills AL. 1991. Classification and characterisation of heterotrophic microbial communities on the basis of patterns of community-level sole-carbon-source utilisation. Applied and Environmental Microbiology 57: 2351-2359.

Gelinas Y, Baldock JA, Hedges JI. 2001. Demineralization of marine and freshwater sediments ${ }^{13} \mathrm{C}$ NMR analysis for CP/MAS. Organic Geochemistry 32: 677-693.

González-Pérez JA, González-Vila FJ, Almendros G, Knicker H. 2004. The effect of fire on soil organic matter-a review. Environment International 30: 855-870.

Green VS, Stottand DE, Diack M. 2006. Assay for fluorescein diacetate hydrolytic activity: Optimization for soil samples. Soil Biology and Biochemistry 38: 693-701.

Gros R, Monrozier LJ, Bartoli F, Chotte JL, Faivre P. 2004. Relationships between soil physico-chemical properties and microbial activity along a restoration chronosequence of alpine grasslands following ski run construction. Applied Soil Ecology 27: 7-22.

Haberhauer G, Rafferty B, Strebl F, Gerzabek MH. 1998. Comparison of the composition of forest soil litter derived from three different sites at various decompositional stages using FTIR spectroscopy. Geoderma 83: 331-342.

Hamman ST, Burke IC, Stromberger ME. 2007. Relationships between microbial community structure and soil environmental conditions in a recently burned system. Soil Biology and Biochemistry 1703-1711.

Hart SC, Newman GS, DeLuca TH, MacKenzie MD, Boyle SI. 2005. Post-fire vegetative dynamics as drivers of microbial community structure and function in forest soils. Forest Ecology and Management 220: 166-184.

Hernández T, Garcia C, Reinhardt I. 1997. Short-term effects of wildfire on the chemical, biochemical, and microbiological properties of Mediterranean pine forest soils. Biology and Fertility of Soils 25: 109-116.

IUSS Working Group WRB. 2006. World reference base for soil resources 2006. 2nd edition. World Soil Resources Reports No. 103. FAO, Rome.

Johnston CT, Aochi YO. 1996. Fourier transform infrared and Raman spectroscopy. p. 269-321. In D.L. Sparks (ed.) Methods of soil analysis. Part 3. SSSA Book Ser. 5. SSSA, Madison, WI.

Johnson DW, Curtis PS. 2001. Effects of forest management on soil C and N storage: meta-analysis. Forest Ecology and Management 140: 227-238.

Kaiser M, Ellerbrock RH. 2005. Functional characterization of soil organic matter fractions different in solubility originating from a long-term field experiment. Geoderma 127: 196-206. 
Keeley JE. 1986. Resilience of Mediterranean shrub communities to fire, Resilience in Mediterranean-type ecosystems: Dordrecht, The Netherlands, Dr W. Junk, p. 95-112.

Knicker H, González-Vila FJ, Polvillo O, Gonzàlez JA, Almendros G. 2005. Fireinduced transformation of $\mathrm{C}$ - and $\mathrm{N}$ - forms in different organic soil fractions from a Dystric Cambisol under a Mediterranean pine forest (Pinus pinaster). Soil Biology and Biochemistry 37: 701-718.

Knicker H, Almendros G, González-Vila FJ, González-Pérez JA, Polvillo O. 2006. Characteristic alterations of quantity and quality of soil organic matter caused by forest fires in continental Mediterranean ecosystems: a solid-state ${ }^{13} \mathrm{C}$ NMR study. European Journal of Soil Science 57: 558-569.

Knicker H. 2007. How does fire affect the nature and stability of soil organic nitrogen and carbon? A review. Biogeochemistry 85: 91-118.

Kogel-Knabner I. 1997. ${ }^{13} \mathrm{C}$ and ${ }^{15} \mathrm{~N}$ NMR spectroscopy as a tool in soil organic matter studies. Geoderma 80: 243-270.

Legendre P, Anderson MJ. 1999. Distance-based redundancy analysis: Testing multispecies responses in multifactorial ecological experiments. Ecological Monograph 69: $1-24$.

Lloret F. 1998. Fire, canopy cover and seedling dynamics in Mediterranean shrublands of Northeastern Spain. Journal of Vegetation Science 9: 417-430.

MacKenzie MD, DeLuca TH, Sala A. 2006. Fire exclusion and nitrogen mineralization in low elevation forests of western Montana. Soil Biology and Biochemistry 38: 952961.

Marion GM, Moreno JM, Oechel WC. 1991. Severity, ash deposition, and clipping effects on soil nutrients in Chaparral. Soil Science Society of America Journal 55: 235240.

Moore JC, de Ruiter PC, Hunt HW. 1993. Influence of productivity on the stability of real and model ecosystems. Science 261: 906-908.

Mulvaney RL. 1996. Nitrogen - Inorganic Forms. In : Sparks DL, Page AL, Helmke PA, Loeppert RH, Soltanpoor PN, Tabatabai MA, Johnston CT, Sumner ME, Methods of soil analysis. Part 3. Chemical Methods-SSSA Book series no. 5. Wisconsin, USA. pp. 1123-1184.

Neary DG, Klopatek CC, DeBano LF, Ffolliott PF. 1999. Fire effects on belowground sustainability: a review and synthesis. Forest Ecology and Management 122: 51-71.

Orwin KH, Wardle DA, Greenfield LG. 2006. Ecological consequences of carbon substrate identity and diversity in a laboratory study. Ecology 87: 580-593. 
Pausas JG, Ribeiro E, Vallejo R. 2004. Post-fire regeneration variability of Pinus halepensis in the eastern Iberian Peninsula. Forest Ecology and Management 203: 251259.

Pietikäinen J, Fritze H. 1995. Clear-cutting and prescribed burning in coniferous forest: Comparison of effects on soil fungal and total microbial biomass, respiration activity and nitrification. Soil Biology and Biochemistry 27: 101-109.

R Development Core Team. 2007. R: A language and environment for statistical computing. R Foundation for Statistical Computing, Vienna, Austria.

Reich PB, Peterson DW, Wedin DA, Wrage K. 2001. Fire and vegetation effects on productivity and nitrogen cycling across a forest-grassland continuum. Ecology 82: 1703-1719.

Rumpel C, Rabia N, Derenne S, Quenea K, Eusterhues K, Kogel-Knabner I, Mariotti A. 2006a. Alteration of soil organic matter following treatment with hydrofluoric acid (HF). Organic Geochemistry 37: 1437-1451.

Rumpel C., Chaplot V., Planchon O., Bernadoux J., Valentin C., Mariotti A. 2006b. Preferential erosion of black carbon on steep slopes with slash and burn agriculture. Catena 65: 30-40.

Rumpel C., Ba A., Darboux F., Chaplot V., Planchon O. 2009. Erosion budget of pyrogenic carbon at meter scale and process selectivity. Geoderma 154: 131-137.

Saiya-Cork KR, Sinsabaugh RL, Zak DR. 2002. The effects of long term nitrogen deposition on extracellular enzyme activity in an Acer saccharum forest soil. Soil Biology and Biochemistry 34: 1309-1315.

Santín C, Knicker H, Fernández S, Menéndez-Duarte R, Álvarez MA. 2008. Wildfires influence on soil organic matter in an Atlantic mountainous region (NW of Spain). Catena 74: 286-295.

Saura-Mas S, Lloret F. 2009. Linking post-fire regenerative strategy and leaf nutrient content in Mediterranean woody plants. Perspectives in Plant Ecology, Evolution and Systematics11: 219-229.

Schaffhauser A. 2009. Impacts de la récurrence des incendies sur la végétation, son inflammabilité et sa combustibilité en forêts de chênes-liège et maquis (Massif des Maures, Var, France). Thèse Université Paul Cézanne (Marseille 3) - Cemagref Aix-enProvence, $283 \mathrm{p}$.

Scheffer M, Carpenter S. 2003. Catastrophic regime shifts in ecosystems: linking theory to observation. Trends Ecology and Evolution 18: 648-656. 
Schimel JP, Firestone MK, Killham KS. 1984. Identification of heterotrophic nitrification in a Sierran forest soil. Applied and Environmental Microbiology 48: 802806.

Schimel JP, Van Cleve K, Cates RG, Clausen TP, Reichardt PB. 1996. Effects of balsam poplar (Populus basamifera) tannins and low molecular weight phenolics on microbial activity in taiga floodplain soil: Implications for changes in $\mathrm{N}$ cycling during succession. Canadian journal of Botany 74: 84-90.

Sinsabaugh RL, Antibus RK, Linkens AE, McClaugherty CA, Rayburn L, Repert, D, Weiland T. 1993. Wood decomposition: nitrogen and phosphorus dynamics in relation to extracellular enzyme activity. Ecology 74: 1586-1593.

Sinsabaugh RL. 2010. Phenol oxidase, peroxidase and organic matter dynamics of soil. Soil Biology and Biochemistry 42: 391-404.

Tabatabai MA, Bremner JM. 1969. Use of p-nitrophenyl phosphate for assay of soil phosphatase activity. Soil Biology and Biochemistry 1: 301-307.

Tinoco P, Almendros G, Sanz J, Gonzalez-Vazquez R, González-Vila FJ. 2006. Molecular descriptors of the effect of fire on soils under pine forest in two continental Mediterranean soils. Organic Geochemistry 37: 1995-2018.

Wan SQ, Hui DF, Luo YQ. 2001. Fire effects on nitrogen pools and dynamics in terrestrial ecosystems: A meta-analysis. Ecological Applications 11: 1349-1365.

Wardle DA. 1998. Controls of temporal variability of the soil microbial biomass - a global-scale synthesis. Soil Biology and Biochemistry 30: 1627-1637.

White CS. 1994. Monoterpenes - Their effects on ecosystem nutrient cycling. Journal of Chemical Ecology 20: 1381-1406.

Wondzell SM, King JG. 2003. Post-fire erosional processes in the Pacific Northwest and Rocky Mountain region. Forest Ecology and Management 178: 75-87. 